\title{
PENGARUH MOTIVASI MENGIKUTI EKSTRAKURIKULER PENDIDIKAN AL-QUR'AN (PAQ) DAN HASIL BELAJAR PENDIDIKAN AGAMA ISLAM (PAI) TERHADAP RELIGIUSITAS SISWA KELAS V SD MASJID SYUHADA YOGYAKARTA
}

\author{
Barirotus Sa'adah \\ STAI Sunan Pandanaran Yogyakarta \\ E-mail Barirotussaadah@gmail.com
}

\begin{abstract}
Penelitian ini bertujuan untuk mengetahui pengaruh motivasi mengikuti ekstrakurikuler PAQ dan hasil belajar PAI terhadap religiusitas siswa SD Masjid Syuhada Yogyakarta.Adapun penelitian ini dilaksanakan pada kelas V SD Masjid Syuhada Yogyakarta. Penelitian ini menggunakan jenis penelitian kuantitatif, pengambilan sampel dalam penelitian ini menggunakan tekhnik random sampling, metode penumpulan data menggunakan observasi, wawancara, angket dan dokumentasi, metode analisis data menggunakan analisis deskriptif dan menggunakan uji asumsi klasik, yang meliputi uji normalitas, uji multikolinieritas dan uji linieritas. Pengujian hipotesis menggunakan regresi linier ganda yang meliputi uji simultan F, uji t dan koefisien determinasi.Pada penelitian ini terdapat dua variabel bebas yaitu motivasi mengikuti ekstrakurikuler PAQ (X1) dan hasil belajar PAI (X2) dan satu variabel terikat yaitu religiusitas siswa (Y). Hasil dari penelitian ini menunjukkan: 1). Tingkat motivasi mengikuti ekstrakurikuler PAQ kelas V SD Masjid Syuhada termasuk kategori sangat baik, hasil belajar PAI kelas V Sd Masjid Syuhada juga dalam kategori sangat baik, dan tingkat religiusitas siswa kelas V SD Masjid Syuhada juga termasuk dalam kategori sangat baik. 2). Motivasi mengikuti ekstrakurikuler PAQ mempunyai pengaruh sebesar 39\% terhadap religiusitas siswa kelas V SD Masjid Syuhada Yogyakarta. 3). Hasil belajar PAI mempunyai pengaruh sebesar 4\% terhadap religiusitas siswa kelas V SD Masjid Syuhada Yogyakarta. 4). Motivasi mengikuti ekstrakurikuler PAQ dan Hasil belajar PAI mempunyai pengaruh secara bersama-sama terhadap religiuaitas siswa kelas V SD Masjid Syuhada Yogyakarta sebesar 43\%, jadi motivasi mengikuti ekstrakurikuler PAQ dan hasil belajar PAI berpengaruh terhadap religiusitas siswa kelas V SD Masjid Syuhada Yogyakarta sebesar $43 \%$ dan selebihnya dipengaruhi oleh faktor lainnya.
\end{abstract}

Kata Kunci: Motivasi, ekstrakurikuler, Hasil belajar PAI, Religiusitas

\section{A. PENDAHULUAN}

Pendidikan Nasional bertujuan mencerdaskan kehidupan dan mengembangkan manusia Indonesia seutuhnya yaitu manusia yang mempunyai nilai religiusitas tinggi, yang beriman dan bertaqwa kepada Tuhan Yang Maha Esa serta berbudi pekerti luhur, memiliki pengetahuan serta ketrampilan, kesehatan jasmani dan rohani, kepribadian yang mantap dan mandiri serta tanggung jawab kemasyarakatan dan kebangsaan. ${ }^{1}$

Tujuan dari pendidikan nasional di atas sejalan dengan tujuan Pendidikan Islam (at-Tarbiyah al-Islamiyah) yaitu mempersiapkan manusia supaya hidup dengan sempurna dan berbahagia,

\footnotetext{
${ }^{1}$ Undang-undang RI No. 2, Tentang Sistem Pendidikan Nasional, (Jakarta: Dharma Bhakti, 1989), hlm. 52
} 
mencintai tanah air, tegap jasmaninya, sempurna budi pekertinya (akhlaknya), teratur pikirannya, halus perasaannya, mahir dalam pekerjaannya, manis tuturkatanya baik dengan lisan atau tulisan. ${ }^{2}$

Berdasarkan undang-undang dasar 1945 pasal 31 ayat 3 yang berbunyi: pemerintah mengusahakan dan menyelenggarakan satu sistem pendidikan nasional yang meningkatkan keimanan dan ketakwaan sertaakhlak mulia (religiusitas)dalam rangka mencerdaskankehidupan bangsa, yang diatur dengan undang-undang. ${ }^{3}$

Religiusitas sebagai sikap atau kesungguhan hati dalam hal menunaikan ajaran agama,sebagaimana disebutkan pula oleh Jalaludin bahwasanya religiusitas ialah sikap keagamaan, yaitu suatu keadaan yang ada dalam diri seseorang yang mendorongnya untuk bertingkah laku sesuai dengan kadar ketaatannya terhadap agama. ${ }^{4}$

Untuk meningkatkan religiusitas sesuai dengan undang-undang di atas, maka diperlukan adanya pendidikan agama untuk mengajarkan nilai-nilai agama pada anak.Pendidikan agama selama ini sudah diterapkan dalam pendidikan formal, karena pendidikan agama di wajibkan di setiap jenjang pendidikan formal.Selain itu, pada beberapa lembaga pendidikan khususnya sekolah dasar juga terdapat kegiatan ekstrakurikuler keagamaan yang dapat membantu menunjang untuk tercapainya tujuan dari Pendidikan Islam. ${ }^{5}$

Kondisi yang memprihatinkan dan mencemaskan dari peradaban masa kini adalah kurangnya perhatian serta minimnya pemahaman tentangajaran agama Islam pada diri anak-anak. Oleh karena itu orang tua siswa sangat mencemaskan hal tersebut, sehingga sangat penting sekali adanya pendidikan anak yang menunjang pada tersampaikannya Pendidikan Agama Islam secara maksimal.Menanggapi permasalahan tersebut, salah satu solusi yang dapat ditempuh ialah dengan adanya Pembelajaran Pendidikan Agama Islam dan kegiatan Ekstrakurikuler Pendidikan Al-Qur'an (PAQ) yang menunjang Pembelajaran pendidikan agama Islam (PAI) di sekolah. ${ }^{6}$

Pendidikan Agama Islam (PAI) menjadi landasan bagi manusia khususnya umat Islam dalam menjalani kehidupannya, tercapai atau tidaknya tujuan dari pembelajaran Pendidikan Agama Islam dapat dilihat dari hasil belajar PAI itu sendiri, yang mana hasil belajar tersebut memuat keseluruhan nilai siswa yang mencakup aspek kognitif, afektif dan psikomotorik. Oleh karenanya, pendidikan

\footnotetext{
${ }^{2}$ Ramayulis, Ilmu Pendidikan Islam, (Jakarta: Kalam Mulia, 1994), hlm. 3-4

${ }^{3}$ Undang-Undang Dasar Republik Indonesia pasal 31 ayat 3 Tahun 1945, (Bandung: CV. Pustaka Setia, 2001), hlm. 45

${ }^{4}$ Jalaluddin, Psikologi Agama, (Jakarta, PT. Raja Grafindo Persada, 1997), hlm. 109.

${ }^{5}$ Wawancara dengan Dra. Muthohharoh (pemrakarsa kegiatan PAQ SD Masjid Syuhada), Kamis 17 Maret, pukul 08.45

${ }^{6}$ Wawancara Dra. Mutoharoh, pencetus pendidikan Al-Qur'an di SD Masjid Syuhada Yogyakarta, Kamis 17 Maret, pukul 08:45.
} 
agama Islam juga sangatlah penting untuk diperhatikan oleh orang tua siswa, sejauh ini mata pelajaran umum masih mendominasi perhatian orang tua, jika hasil belajar pelajaran umum kurang baik, maka orang tua akan bingung dan segera mendaftarkan putra-putrinya ke salah satu lembaga bimbingan belajar, namun sebaliknya, jika hasil belajar dari mata pelajaran pendidikan agama Islam kurang baik, orang tua tidak merasa khawatir.

Sesuai dengan Visi dan Misi dari SD Masjid Syuhada, yaitu menumbuhkembangkan penghayatan dan pengamalan terhadap ajaran agama Islam, menuju siswa yang beriman dan bertaqwa kepada Allah SWT. Sekolah Dasar Masjid Syuhada Yogyakarta dalam melaksanakan pendidikan jugamelaksanakan kegiatan pembelajaran pendidikan agama Islam(PAI) dan ekstrakurikuler pendidikan al-qur'an (PAQ) untuk para siswanya, pengertian dari ekstrakurikuler itu sendiri ialah kegiatan yang langsung menunjang kurikulum dalam membentuk pribadi siswa yang seutuhnya. $^{7}$

Alasan mengapa Sekolah Dasar Masjid Syuhada selain melaksanakan kegiatan pembelajaran pendidikan agama Islam (PAI)SD Masjid Syuhada juga melaksanakan ekstrakurikuler pendidikan alQur'an (PAQ) ialah, karena dirasa sangat pentingnya Pemahaman Pendidikan Agama Islam yang utuh bagi siswa dalam menghadapi tantangan globalisasi, dimaksudkan dengan adanya kegiatan ekstrakurikuler pendidikan al-qur'an (PAQ) tersebut, akan membantu pendalaman pendidikan agama Islam siswa, yang akan tercermin pada tingkah lakunya dalam kehidupan sehari-hari, yang nantinya akan menjadi bekal hidup seterusnya. ${ }^{8}$ Berangkat dari latar belakang tersebut, peneliti tertarik untuk melakukan penelitian terhadap pengaruh motivasi mengikuti ekstrakurikuler pendidikan al-Qur'an (PAQ) dan hasil belajarpendidikan agama Islam (PAI) terhadap religiusitas Siswa kelas V SD Masjid Syuhada Yogyakarta.

\section{B. KAJIAN TEORI}

\section{Motivasidan Ekstrakurikuler PAQ (Pendidikan Al-Qur,an)}

Kata motivasi berasal dari kata motif yang memiliki arti daya penggerak dalam diri seseorang untuk melakukan aktivitas tertentu, demi mencapai suatu tujuan. Kemudian, Istilah motivasi yang berasal dari kata motif tersebut juga diartikan sebagai kekuatan yang terdapat dalam diri individu, sehingga menyebabkan individu bertindak atau berbuatsuatu hal, motivasi merupakan

\footnotetext{
${ }^{7}$ Hadari Nawawi, dkk, Administrasi Sekolah, (Jakarta: Ghalia Indonesia, 1986), hlm. 160

${ }^{8}$ Wawancara kepada Bpk. Syaif, Kepala Sekolah SD Masjid Syuhada Yogyakarta 1, selasa 12 Januari, pukul 08.10 WIB.
} 
sebuahdorongan yang terdapat dalam diri seseorang untuk berusaha mengadakan perubahan tingkah laku yang lebih baik dalam memenuhi kebutuhannya. Motif tidak dapat diamati secara langsung, tetapi dapat di interprestasikan melalui tingkah laku, motif berupa rangsangan, dorongan, atau pembangkit tenaga munculnya suatu tingkah laku tertentu. ${ }^{9}$

Kemudian, Secara garis besar, motivasi itu mempunyai fungsi sebagai berikut:

a. Mendorong manusia untuk berbuat atau bertindak.

b. Menentukan arah perbuatan, yaitu ke arah tujuan yang hendak dicapai.

c. Menyeleksi perbuatan, yakni menentukan perbuatan-perbuatan apa yang harus dikerjakan yang serasi guna mencapai tujuan. ${ }^{10}$

Motivasi yang merupakan penggerak pada seseorang untuk melakukan suatu hal dalam mencapai sebuah tujuan mempunyai beberapa indikator sebagai berikut:

a. Motivasi intrinsic

Para psikolog menjelaskan motivasi instrinsik sebagai dorongan kearah pengoptimalisasian stimulan (adanya keseimbangan antara aktivitas yang sangat sulit dan aktivitas yang sangat mudah), pintrich dan sucnk (1996), menyatakan bahwa motivasi instrinsik merupakan motivasi untuk melakukan aktivitas itu sendiri menjadi hadiah bagi individu itu sendiri. ${ }^{11}$ Motivasi intrinsik dalam diri seseorang dmemiliki indicator diantaranya: Perasaan senang, kemauan dan kecerdasan.

b. Motivasi ekstrinsik

Motivasi ekstrinsik adalah hal atau keadaan yang datang dari luar individu, yang juga mendorongnya untuk melakukan kegiatan belajar.Seperti pujian dan hadiah, peraturan, suri tauladan dari orang tua, guru dan sebagainya. ${ }^{12}$ Dorongan dapat berupa : Dorongan dari guru, dorongan dari orang tua dan dorongan dari teman.

Eksrakurikuler ialah kegiatan diluar mata pelajaran dan bimbingan konseling, yang dimaksudkan untuk membantu pengembangan peserta didik, sesuai dengan kebutuhan, potensi, dan bakat melalui kegiatan yang secara khusus dilaksanakan oleh pendidik atau tenaga kependidikan, yang berkemampuan atau berkewenangan di sekolah atau madrasah. ${ }^{13}$

\footnotetext{
${ }^{9}$ Hamzah B. Uno, Teori Motivasi dan Pengukurannya analisis di bidang pendidikan, (Jakarta: PT. Bhumi Aksara, 2008), hlm. 3

${ }^{10} \mathrm{Ibid}$..., hlm. 3

${ }^{11}$ Esa Nur Wahyuni, Motivasi Dalam Pembelajaran, (Malang: UIN Malang Press, 2009), hlm. 109

${ }^{12}$ Muhibbin Syah, Psikologi Belajar, (Jakarta: Logos, 1999), hlm. 136-137

${ }^{13}$ Muhaimin dkk, Pengembangan Model KTSP pada Sekolah dan Madrasah, (Jakarta: Raja Grafindo Persada, 2008), hlm. 74
} 
Salah satu dari kegiatan ekstrakurikuler ialah kegiatan ekstrakurikuler keagamaanyang mempunyai peranan penting dalam mengembangkan pengetahuan keagamaan siswa. Sebagaimana tersebut dalam tujuan pelaksanaan ekstrakurikuler di sekolah menurut Direktoral Pendidikan Menengah Kejuruan (1987) sebagai berikut:

a. Kegiatan ekstrakurikuler harus meningkatkan kemampuan siswa dalam aspek kognitif, afektif dan psikomotorik.

b. Mengembangkan bakat dan minat siswa dalam upaya pembinaan pribadi menuju pembinaan manusia seutuhnya yang positif.

c. Siswa dapat mengetahui, mengenal serta membedakan adanya hubungan satu pelajaran dan pelajaran lainnya. ${ }^{14}$

Kegiatan ekstrakurikuler membantu siswa untuk mempunyai semangat baru agar lebih giat belajar serta menanamkan tanggung jawabnya sebagai warga negara yang mandiri.Dalam ekstrakurikuler dikembangkan pengalaman-pengalaman yang bersifat nyata yang dapat membawa siswa kepada kesadaran atas pribadi, sesama dan Tuhan-nya.

Kegiatan ekstrakurikuler PAQ (Pendidikan Al-Qur'an) merupakan kegiatan ekstrakurikuler yang diharapkan dapat menunjang pembelajaran pendidikan agama Islam yang ada di Sekolah Dasar Masjid Syuhada, yang mana materi yang di ajarkan dalam kegiatan ekstrakurikuler tersebut ialah meliputi: Tajwid dan carabaca tulis al-Qur'an, doa-doa sehario-hari, surat-surat pendek, penuliasan khot yang baik, hadits-hadits dan beberapa pengethauan tentang keagamaan lainnya. ${ }^{15}$

Motivasi mengikuti kegiatan ekstrakurikuler PAQ ialah bagaimana semangat/dorongan dari dalam maupun luar diri siswa dalam mengikuti proses pembelajaran PAQ di kelas.

\section{Tinjauan Tentang Hasil Belajar PAI}

Penilaian adalah proses pengumpulan dan pegolahan informasi untuk menentukan pencapaian hasilbelajar peserta didik. Berdasarkan pada PP Nomor 19 tahun 2005 tentang standar nasional pendidikan bahwa penilaian pendidikan pada jenjang pendidikan dasar dan menengah terdiri atas:

a. Penilaian hasil belajar oleh pendidik

b. Penilaian hasil belajar oleh satuan pendidikan

c. Penilaian hasil belajar oleh pemerintah ${ }^{16}$

\footnotetext{
${ }^{14}$ Suryobroto, Proses Belajar Mengajar di Sekolah (Jakarta: PT Rineka Cipta, 1997), hlm. 272.

${ }^{15}$ Wawancara dengan Kepala Sekolah SD Masjid Syuhada Yogyakarta 1, selasa 12 Januari, pukul 08.10 WIB.

${ }^{16}$ Peraturan Pemerintah Republik Indonesia Nomor 19 Tahun 2005 tentang Standar Nasional Pendidikan.
} 
Berdasarkan peraturan pemerintah di atas, setiap satuan pendidikan selain melakukan perencanaan dan proses pembelajaran, juga melakukan penilaian hasil pembelajaran sebagai upaya terlaksanannya proses pembelajaran yang efektif dan efisien.

Kemudian dalam hal ini di maksudkan bahwa hasil belajar PAI ialah, nilai-nilai, kemampuankemampuan yang diperoleh siswa setelah mengikuti kegiatan belajar mengajar dalam mata pelajaran PAI yang kemudian mereka tunjukkan dalam nilai hasil ulangan harian, mengerjakan tugas maupun hasil ujian, setelah itu guru PAI menyimpulkannya melalui angka-angka.Adapun materi kajian pendidikan agama Islam dapat dikalsifikasikan sebagai berikut: Aspek al-Qur'an Hadits, aspek keimanan, aspek akhlak, dan aspek hokum Islam.

1) Aspek-aspek hasil belajar PAI

a) Aspek hasil belajar kognitif dalam mata pelajaran PAI

Salah satu sasaran hasil belajar PAI ialah aspek kognitif.Aspek kognitif ialah aspek yang berkaitan dengan kemampuan berpikir. Menurut teori yang dikemukakan oleh Benjamin S. Bloom dkk, aspek kognitif terdiri dari: Tingkat kemampuan mengingat, tingkat kemampuan memahami, tingkat kemampuan mengaplikasikan, tingkat kemampuan menganalisis, tingkat kemampuan mengevaluasi dan tingkat kemampuan mencipta. ${ }^{17}$

b) Aspek hasil belajar afektif

Selain aspek kognitif, aspek lain dari penilaian hasil belajar PAI ialah aspek afektif, yang mana dalam hal ini merupakan penilaian terhadap sikap dan perilaku siswa.Berikut beberapa aspek hasil belajar PAI ranah afektif diantaranya: Receiving atau attending (Kepekaan), responding, Valuing, Organization, Karakterisasi. ${ }^{18}$

c) Aspek belajar psikomotorik

Hasil belajar psikomotor dalam pembelajaran PAI diantaranya: Persepsi, Kesiapan, Gerakan terbimbing, Gerakan terbiasa, Gerakan komplek, Gerakan pola penyesuaian Kreativitas $^{19}$

\section{Tinjauan tentang Religiusitas}

\section{Religiusitas}

${ }^{17}$ Lorin W Anderson\&David R Krathwol, Kerangka Landasan Untuk Pembelajaran Pengajaran dan Asesmen, (Yogyakarta: PPustaka Pelajar, 2010), hlm. 100-102

${ }^{18}$ Sukiman, Pengembangan Sistem Evaluasi PAI(Yogyakarta: Jurusan PAI Fakultas Tarbiyah, 2008), hlm. $55-57$

${ }^{19}$ Ibid ., hlm. 58-40 
Menurut kamus umum bahasa Indonesia, kata lain dari religiusitas adalah saleh atau kesalehan yang memiliki arti taat dan sungguh-sungguh menjalankan agamanya atau kesungguhan hati dalam hal menunaikan ajaran agamanya. ${ }^{20}$ Jalaluddin menyebutkan bahwa religiusitas sebagai sikap keagamaan, yaitu suatu keadaan yang ada dalam diri seseorang yang mendorongnya untuk bertingkah laku sesuai dengan kadar ketaatannya terhadap agama. ${ }^{21}$

Seperti yang terdapat dalam sabda Nabi Muhammad SAW:

"Dari Abu Hurairah r.a berkata, Bersabda Rasulullah SAW.Tiada anak lahir (dilahirkan) kecuali dalam keadaan fitrah, maka kedua orang tuanya yang akan menjadikan Yahudi, Nasrani atau Majusi”. (HR. Bukhari). ${ }^{22}$

Menurut Glock dan Stark, sebagaimana dikutip oleh Djamaludin, ada lima dimensi religiusitas yang ada pada diri seseorang. ${ }^{23}$

a. Dimensi keyakinan (Iman)

Dimensi keyakinan atau akidah Islam menunjuk pada seberapa tingkat keyakinan Muslim terhadap kebenaran ajaran-ajaran agamanya, terutama terhadap ajaran-ajaran yang bersifat fundamental dan dogmatik.Di dalam keberislaman, isi dimensi keimanan menyangkut tentang keyakinan kepada Allah SWT, para malaikat, Nabi/Rasul, kitabkitab Allah, hari kiamat (surga dan neraka), serta taqdir Allah (qadha dan qadar).

b. Dimensi praktek agama (Islam)

Dimensi peribadatan (atau praktek agama)menunjukkan pada seberapa tingkat kepatuhan Muslim dalam mengerjakan kegiatan-kegiatan ritual peribadatan, sebagaimana yang telah diajarkan oleh agamanya. Dalam keberislaman, dimensi peribadatan menyangkut pelaksanaan shalat, puasa, zakat, haji, membaca Al-Qur'an, doa, zikir, ibadah kurban, iktikaf di masjid dibulan puasa dan sebagainya.

c. Dimensi pengalaman (Ihsan)

Dimensi pengalaman atau penghayatan adalah dimensi yang menyertai keyakinan, perilaku dan peribadatan.Dimensi penghayatan menunjuk pada seberapa jauh tingkat Muslim dalam merasakan dan mengalami perasaan-perasaan dan pengalamanpengalaman religius.Dimensi ini terwujud dalam perasaan seseorang yang dekat/akrab dengan Allah, perasaan tentram bahagia karena percaya dan sangat dekat dengan Allah

\footnotetext{
${ }^{20}$ W.J.S.Poerwadarminta, Kamus Umum Bahasa Indonesia (Jakarta: PN Balai Pustaka, 1976), hlm. 856.

${ }^{21}$ Jalaluddin, Psikologi Agama, (Jakarta, PT. Raja Grafindo Persada, 1997), hlm. 109.

${ }^{22}$ Lidwa Pustaka i-Software, Kitab Bukhari, Nomor Hadis 1270.

23 Jamaludin Ancok dan Fuad Nashori Suroso, Psikologi Islami: Solusi Islam atas Problem-problem Psikologi, (Yogyakarta: Pustaka Pelajar, 1994), hlm.80
} 
SWT, perasaan khusuk ketika melaksanakan shalat atau berdoa dan ketika melaksanakan ibadah lainnya.

d. Dimensi pengetahuan agama (Ilmu)

Dimensi pengetahuan atau ilmumenunjuk pada seberapa tingkat pengetahuan dan pemahaman Muslim terhadap ajaran-ajaran agamanya, terutama mengenai ajaranajaran pokok dari agamanya, sebagaimana termuat dalam kitab sucinya. Dimensi ini menyangkut pengetahuan tentang isi Al-Qur'an, hadiits dan sunnah rosul, yang merupakan pokok-pokok ajaran yang harus diimani dan dilaksanakan (rukun Islam dan rukun iman), hukum-hukum Islam, sejarah Islam dan sebagainya.

e. Dimensi pengalaman (amal)

Dimensi pengalaman atau akhlak menunjuk pada seberapa tingkatan Muslim dalam berperilaku yang dimotivasi oleh ajaran-ajaran agamanya, yaitu bagaimana individu menjalani kehidupannya, hubungan dengan Allah dan dengan manusia lainnya.Dimensi ini dapat berupa perilaku suka menolong, bekerjasama, saling menghormati, menyejahterakan dan menumbuhkembangkan orang lain, menegakkan keadilan dan kebenaran, berlaku jujur, memaafkan, menjaga lingkungan hidup dan sebagainya.

\section{Religiusitasusia anak-anak}

Menurut beberapa ahli, anak dilahirkan dalam keadaan kosong seperti kertas putih, belum membawa apapun, lalu bagaimana rasa keagamaan pada diri anak-anak mulai tumbuh? Berikut beberapa teori tentang pertumbuhan keagamaan pada anak, antara lain:

a. Rasa ketergantungan (sense of depend)

Teori ini dikemukakan oleh Thomas melalui teori Four Whises. Menurutnya, manusia dilahirkan ke dunia ini memiliki empat keinginan yaitu: keinginan untuk perlindungan (security), keinginan akan pengalaman baru (new experience), keinginan untuk mendapat tanggapan (Response), dan keinginan untuk dikenal (recognation). ${ }^{24}$

b. Insting keagamaan

Menurut Woodworth, bayi yang sudah dilahirkan memiliki beberapa insting di antaranya insting keagamaan. Belum terlihatnya tindak keagamaan pada diri anak karena beberapa fungsi kejiwaan yang menopang kematangan berfungsinya insting itu belum sempurna. $^{25}$

\footnotetext{
${ }^{24}$ Jalaludin, Psikologi Agama, (Jakarta: PT. Raja Gravindo, 2009), hlm. 64-65

${ }^{25}$ Ibid, ..., hlm.64-65
} 


\section{Sifat-Sifat Agama Pada Anak}

Memahami konsep agama pada anak berarti memahami sifat-sifat agama pada anak, ide keagamaan pada anak hampir sepenuhnya autoritarius, maksudnya konsep keagamaan pada diri mereka dipengaruhi oleh faktor dari luar diri mereka. Karena mereka akan mengikuti dan melakukan apa yang telah dikerjakan oleh orang dewasa, terutama orang tua dan guru mereka. Oleh karena itu ketaatan kepada agama merupakan kebiasaan yang menjadi milik dari mereka. Bagi mereka sangatlah mudah mengikuti apa yang diajarkan oleh orang tua dan guru mereka, meskipun mereka belum mengerti sepenuhnya apa manfaat dari apa yang mereka pelajari, oleh karena itu sifat-sifat keagamaan pada diri anak, terdiri atas:

a. Unreflective (Tidak Mendalam)

Dalam penelitian Machion tentang sejumlah konsep ke-Tuhanan pada diri anak, 73\% mereka menganggap Tuhan itu bersifat seperti manusia.Anggapan mereka terhadap ajaran agama dapat mereka terima dengan tanpa kritik. Kebenaran yang mereka terima tidak begitu mendalam, sehingga cukup sekedarnya saja dan mereka sudah merasa puas dengan keterangan yang kadang-kadang kurang masuk akal, meskipun demikian, pada beberapa anak memiliki ketajaman pikiran untuk menimbang pendapat yang mereka terima dari orang lain. ${ }^{26}$

b. Egosentris

Anak memiliki kesadaran akan diri sendiri sejak tahun pertama usia perkembangannya dan akan berkembang sejalan dengan pertambahan pengalamannya. Apabila kesadaran akan diri itu mulai subur pada diri anak, maka akan tumbuh keraguan pada rasa egonya. Semakin bertumbuh, semakin meningkat pula egonya, sehubungan dengan hal itu, maka dalam masalah keagamaan anak telah menonjolkan kepentingan dirinya yang telah menuntut konsep keagamaan yang mereka pandang dari kesenangan pribadinya. Seorang anak yang kurang mendapat kasih sayang dan selalu mengalami tekanan akan bersifat kekanak-kanakan (childish) dan memiliki sifat ego yang rendah. Hal tersebut mengganggu pertumbuhan keagamaannya. ${ }^{27}$

c. Antromorphis

\footnotetext{
${ }^{26}$ Jalaludin, Psikologi Agama ..., hlm. 70

${ }^{27}$ Ibid,..., hlm. 70
} 
Pada umumnya, konsep mengenai kaTuhanan pada anak berasal dari pengalamannya ketika ia berhubungan dengan orang lain. Tapi suatu kenyataan bahwa konsep ke-Tuhanan mereka tampak jelas menggambarkan aspek-aspek kemanusiaan. ${ }^{28}$

Melalui konsep yang terbentuk dalam pikiran, mereka menganggap bahwa keadaan Tuhan itu sama dengan manusia. Pekerjaan Tuhan mencari dan menghukum orang yang berbuat jahat disaat orang itu berada dalam tempat yan gelap.

Mereka menganggap tuhan berada dilangit, dan dapat melihat langsung dari atas semua perbuatan manusia, dari rumah manusia masing-masing tersebut. Pada anak usia 6 tahun, praff dalam penelitiannya, menyebutkan pandangan anak-anak terhadap tuhannya sebagai berikut:Tuhan memiliki wajah seperti manusia, memiliki telinga yang besar dan lebar, Tuhan tidak pernah makan tetapi hanya meminum air embun, begitulah pandangan anak tentang Tuhan berdasarkan fantasinya masing-masing.

d. Verbalis dan Ritualis

Berdasarkan pengalaman dan kenyataan, pengalaman keagamaan anak-anak tumbuh mula-mula secara verbal (ucapan), mula-mula anak-anak diajari oleh orang tua, guru serta lingkungan untuk menghafal hal-hal keagamaan secara verbal, mungkin hal tersebut dinilai kurang mempunyai hubungan dengan tingkat keagamaan pada anak, tapi menurut penelitian ang ada, hal tersebut sangat berpengaruh pada tingkat keagamaan anak diusia remaja maupun dewasa. Banyak orang-orang dewasa yang melakukan praktik keagamaan berdasarkan apa yang mereka pelajari sejak kecil, kemudian sebaliknya, jika seseorang belajar tentang keagamaan ketika sudah dewasa, maka akan mengalami kesukaran/kesulitan. ${ }^{29}$

e. Imitatife

Sifat imitatife ini, keagamaan anak-anak dimulai dari meniru apa yang mereka perhatikan pada lingkungannya, misalnya mereka akan meniru cara sholat dan berdoa dari orang tua, guru, serta lingkungannya, oleh karena itu dalam hal ini perlu dibudayakan pengajaran yang baik oleh orang tua, guru, juga lingkungan.

\footnotetext{
${ }^{28} \mathrm{Ibid}, \ldots, \mathrm{hlm} .70$

${ }^{29}$ Jalaludin, Psikologi Agama, .., hlm.70-74
} 
Menurut gillesphy dalam penelitiannya, yang menyatakan bahwa anak yang tidak mendapatkan pendidikan agama dalam keluarga tidak akan dapat diharapkan menjadi pemilik kematangan dalam beragama. ${ }^{30}$

Walaupun anak mendapatkan ajaran agama tidak semata-mata berdasarkan apa yang mereka peroleh semasa kecil, namun pendidikan keagamaan (religious pedagogis) sangat mempengaruhi terwujudnya tingkah laku keagamaan (religious behavior) melalui sifat meniru tersebut.

f. Rasa heran

Rasa heran dan kagum merupakan salah satu tanda dan sifat keagamaan pada anak. Berbeda dengan rasa kagum yang terjadi pada orang dewasa, rasa kagum yang ada pada anak belum bersifat kritis dan kreatif, mereka hanya kagum terhadap keadaan lahiriah saja, hal itu merupakan langkah pertama dari pernyataan anak akan dorongan untuk mengenal sesuatu yang baru (new experience), rasa kagum mereka dapat disalurkan melalui cerita-cerita yang menimbulkan rasa takjub. ${ }^{31}$

Teori-teori tentang sikap keagamaan pada anak di atas, menjelaskan bahwasanya rasa keagamaan telah ada pada diri anak sejak mereka lahir, kemudian seiring bertambahnya usia, mereka akan mulai mencari dengan cara meniru serta mempelajari nilai-nilai/ajaran agamanya dari orang tua, guru, teman maupun lingkungan sekitarnya. Oleh sebab itu, semua komponen yang menjadi sumber dari pengetahuan agama dari anak tersebut sebaiknya dapat memberi contoh dengan baik

Kemudian, dari pemaparan tentang Religiusitas usia anak kemudian dimensi keagamaan pada usia anak-anak seperti pengertian yang dipaparkan oleh Glock di atas yang meliputi:

a. Dimensi keyakinan

Aspek ini menyangkut system keimanan atau kepercayaaan terhadap Allah SWT yang meliputi rukun iman dan rukun Islam, hal ini menjadi alasan yang sangat fundamental dalam keseluruhan aktivitas seorang muslim, baik yang menyangkut sikap mental atau tingkah lakunya dan sifat-sifat yang ia miliki. ${ }^{32}$

\footnotetext{
${ }^{30}$ Ibid..., hlm.73

${ }^{31}$ Jalaludin, Psikologi Agama,..., hlm,70-74

${ }^{32}$ Departemen Pendidikan Nasional, Pedoman Umum Standar Kompetensi Mata Pelajaran PAI SMP dan Mts, (Jakarta: Puskur, 2003), hlm. 7
} 
Dimensi iman, yang meliputi kepercayaan serta hubungan anak terhadap Allah, kepada malaikat, kepada kitab, kepada Rosul, kepada hari kiamat dan takdir Allah.

\section{b. Dimensi Praktek Agama}

Salah satu dimensi praktek agama dapat dilihat dari ibadah seseorang, pengertian ketaatan sebagaimana disebutkan dalam kamus besar bahasa Indonesia berarti kepatuhan, kesetiaan, sedangkan Ibadah yang berasal dari kata "abada" yang berarti menyembah menghinakan diri kepada Alla

Dimensi Islam ialah intensitas dalam pelaksanaan ibadah anak yang meliputi Syahadatain (kesaksian anak bahwa tidak ada tuhan selain Allah, dan Nabi Muhammad SAW utusan Allah), pelaksanaan sholat wajib dan sunnah dalam kehidupan sehari-hari, pelaksanaan pembiasaan membayar zakat, pelaksanaan puasa pada bulan Ramadhan dan pembelajaran tentang haji.

c. Dimensi Pengalaman

Dimensi ihsan ialah pengalaman dan perasaan anak akan kehadiran Tuhan, ia merasa seakan-akan selalu di awasi oleh Allah SWT, merasa seakan-akan dilihat oleh Allah SWT ketaqwaan anak, pelaksanaan semua peritah Allah SWT dan kegiatan menjauhi segala larangan Allah SWT, serta keyakinan anak akan adanya balasan (dosa) dan imbalan (pahala).

d. Dimensi Pengetahuan Agama

Dimensi ilmu ialah, pengetahuan anak tentang agamanya, serta ajaran yang ada dalam agamanya.

e. Dimensi Pengamalan

Dimensi amal ialah merupakan perwujudan dalam tingkah laku sehari-hari tentang segala pengetahuan yang telah dipahami dan dipelajari oleh anak.

\section{METODE PENELITIAN}

Jenis penelitian yang digunakan adalah penelitian kuantitatif ${ }^{33}$. Lokasi Penelitian ini adalah SD Masjid Syuhada Yogyakarta, Sample dalam penelitian adalah Siswa kelas VA, B, C dan

\footnotetext{
${ }^{33}$ Zainal Arifin, Penelitian Pendidikan, (Bandung: Remaja RosdaKarya, 2011), hlm. 29
} 
D yang berjumlah 120 siswa, peneliti menggunakan tekhnik simple random sampling. ${ }^{34}$ Metode pengumpulan data dalam penelitian ini menggunakan Angket, Wawancara, observasi dan dokumentasi.

Metode analisis data yang peneliti gunakan adalah analisis kuantitatif dengan menggunakan SPSS yang meliputi: Analisis statistik deskriptif, dan uji asumsi klasik. Dalam Uji asumsi klasik dilakukan Uji normalitas, Uji Multikolonieritas, dan Uji Linearitas.Kemudian, dalam Pengujian hipotesis menggunakan Pengujian hipotesis Regresi Linear Ganda, Mencari uji serentak/simultan F, Pengujian hipotesis secara Parsial (Uji statistik t), dan Koefisien determinasi. $^{35}$

\section{PEMBAHASAN}

Berdasarkan pengujian hipotesis dan hasil pembahasan dari hasil penelitian mengenai pengaruh motivasi mengikuti ekstrakurikuler PAQ dan hasil belajar PAI terhadap religiusitas siswa kelas V SD Masjid Syuhada Yogyakarta menunjukkan hasil sebagai berikut:

1. Motivasi mengikuti kegiatan ekstrakurikuler PAQ mempunyai pengaruh yang signifikan terhadap religiusitas siswa kelas V SD Masjid Syuhada Yogyakarta. Hal tersebut di buktikan buktikan dengan uji t pada taraf signifikansi 0,05. Dari analisis data diperoleh harga $t=8,403$ dan nilai sig. $=0,000$. Karena nilai sig. kurang dari 0,05 dapat disimpulkan bahwa ada pengaruh dari motivasi megikuti ekstrakurikuler PAQ terhadap religiusitas siswa kelas $\mathrm{V}$ Sekolah Dasar Masjid Syuhada Yogyakarta.Selanjutnya, kontribusi murni dari variabel motivasi mengikuti ekstrakurikuler PAQ terhadap religiusitas siswa kelas V SD Masjid Syuhada Yogyakarta diketahui dari perhitungan koefisien determinasi parsial sebesar 0,39,

\footnotetext{
${ }^{34}$ Sugiyono, Metode Penelitian Pendidikan "pendekatan kualitatif, kuantitatif dan R\&D, (Bandung: Alfabeta, 2010)", hlm. 120

${ }^{35}$ Nana Syaodih Sukmadinata, Metode Penelitian Pendidikan, (Bandung: PT. Remaja Rosdakarya, 2009), hlm. 53
} 
sehingga dapat disimpulkan bahwa pengaruh motivasi mengikuti ekstrakurikuler PAQ terhadap religiusitas siswa mempunyai kontribusi murni sebesar 39\%..

2. Hasil belajar PAI mempunyai pengaruh yang signifikan terhadap religiusitas siswa kelas V SD Masjid Syuhada Yogyakarta. Hal tersebutdibuktikan dengan menggunakan uji t pada taraf signifikansi 0,05 . Dari data di atas diperoleh harga $\mathrm{t}=2,365$ dan nilai sig. $=0,000$, karena nilai sig. kurang dari 0,05 dapat disimpulkan bahwa ada pengaruh hasil belajar PAI terhadap religiusitas siswa kelas V Sekolah Dasar Masjid Syuhada Yogyakarta.Selanjutnya, kontribusi murni dari variabel hasil belajar PAI terhadap religiusitas siswa kelas V SD Masjid Syuhada Yogyakarta diketahui dari perhitungan koefisien determinasi parsial sebesar 0,04, sehingga pengaruh motivasi mengikuti ekstrakurikuler PAQ terhadap religiusitas siswa mempunyai kontribusi murni sebesar $4 \%$.

3. Motivasi mengikuti kegiatan ekstrakurikuler PAQ dan hasil belajar PAI secara bersama-sama mempunyai pengaruh terhadap religiusitas siswa kelas V SD Masjid Syuhada Yogyakarta. Untuk pengujian hipotesis yang ketiga ini, telah dilakukan analisis regresi ganda dua variabel bebas (X1 dan X2) dengan satu variabel terikat (Y). Besarnya pengaruh ke dua variabel bebas terhadap variabel terikat di ketahui dari nilai $\mathrm{R}$ square, nilai dari $\mathrm{R}$ square $=0,430$. Jadi dengan begitu kedua variabel bebas memberikan kontribusi sebesar 43\% terhadap variabel terikat. Kemudian untuk mengetahui signifikan tidaknya pengaruh variabel bebas motivasi mengikuti kegiatan ekstrakurikuler PAQ dan hasil belajar PAI terhadap variabel terikat Religiusitas siswa kelas V SD Masjid Syuhada maka dilakukan uji F. hasil perhitungan memberikan nilai F sebesar 40,437. Sesuai kriteria pengujian yang telah ditetapkan. Diperoleh nilai sig. $=0,000<0,05$ maka pengaruh tersebut signifikan. Dengan demikian disimpulkan bahwa ada pengaruh yang signifikan dari motivasi mengikuti ekstrakurikuler PAQ dan hasil 
belajar PAI secara bersama-sama terhadap religiusitas siswa kelas V SD Masjid Syuhada Yogyakarta.

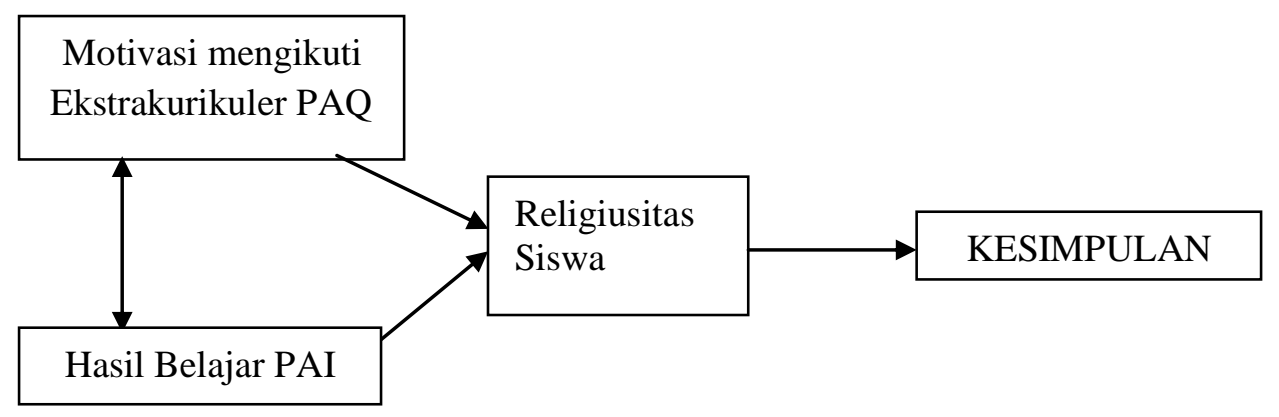

\section{E. PENUTUP}

Hasil analisis dari Pengaruh Motivasi mengikuti Ekstrakurikuler PAQ dan Hasil Belajar PAI terhadaap Religiusitas Siswa Kelas V SD Masjid Syuhada Yogyakarta di ketahui dari nilai Rsquare sebesar 0,430. Jadi dengan begitu kedua variabel bebas memberikan kontribusi sebesar 43\% terhadap variabel terikat.Kemudian untuk hasil perhitungan signifikan nilai F sebesar 40,437.Sesuai kriteria pengujian yang telah ditetapkan. Diperoleh nilai sig. $=0,000<0,05$ maka pengaruh tersebut signifikan. Dengan demikian disimpulkan bahwa ada pengaruh yang signifikan dari motivasi mengikuti ekstrakurikuler PAQ dan hasil belajar PAI secara bersama-sama terhadap religiusitas siswa kelas V SD Masjid Syuhada Yogyakarta.

\section{F. DAFTAR PUSTAKA}

Arifin Zainal. 2011. Penelitian Pendidikan, Bandung: Remaja RosdaKarya. 
B. Uno Hamzah. 2008.Teori Motivasi dan Pengukurannya analisis di bidang pendidikan, Jakarta: PT. Bhumi Aksara.

Departemen Pendidikan Nasional. 2003.Pedoman Umum Standar Kompetensi Mata Pelajaran PAI SMP dan Mts, Jakarta: Puskur.

Hadari Nawawi, dkk. 1986. Administrasi Sekolah, Jakarta: Ghalia Indonesia.

Jalaluddin.1997. Psikologi Agama, Jakarta: PT. Raja Grafindo Persada.

Muhaimin dkk. 2008.Pengembangan Model KTSP pada Sekolah dan Madrasah, Jakarta: Raja Grafindo Persada.

Muhibbin Syah. 1999.Psikologi Belajar, Jakarta: Logos.

Nana Syaodih Sukmadinata. 2009.Metode Penelitian Pendidikan, Bandung: PT. Remaja Rosdakarya.

Nur Wahyuni Esa. 2009.Motivasi Dalam Pembelajaran, Malang: UIN Malang Press.

Peraturan Pemerintah Republik Indonesia Nomor 19 Tahun 2005 tentang Standar Nasional Pendidikan

Ramayulis. 1994.Imu Pendidikan Islam, Jakarta: Kalam Mulia.

Sugiyono.2010.Metode Penelitian Pendidikan "pendekatan kualitatif, kuantitatif dan R\&D, Bandung: Alfabeta.

Suryobroto.1997.Proses Belajar Mengajar di Sekolah Jakarta: PT Rineka Cipta.

Undang-Undang Dasar Republik Indonesia pasal 31 ayat 3 Tahun 1945, 2001, Bandung: CV. Pustaka Setia.

Undang-undang RI No. 2, 1989, Tentang Sistem Pendidikan Nasional, Jakarta: Dharma Bhakti. 